\title{
HUBUNGAN MINAT MEMILIH KOMPETENSI KEAHLIAN TERHADAP HASIL BELAJAR MENGGAMBAR DENGAN AUTOCAD PADA SISWA KELAS XI TEKNIK GAMBAR BANGUNAN SMK NEGERI 1 LUBUK PAKAM
}

\author{
Asmita Silitonga ${ }^{1}$, Toyama Sitompul ${ }^{2}$ \\ ${ }^{1}$ Alumni Program Studi Pendidikan Teknik Bangunan, Fakultas Teknik UNIMED \\ ${ }^{2}$ Dosen Pengajar Jurusan Pendidikan Teknik Bangunan, Fakultas Teknik UNIMED \\ (toyamasitompul@gmail.com)
}

\begin{abstract}
ABSTRAK
Penelitian ini bertujuan untuk mengetahui: Adanya hubungan yang positif dan signifikan antara Minat Memilih Kompetensi Keahlian Terhadap Hasil Belajar Menggambar Dengan Autocad Pada Siswa Kelas XI Teknik Gambar Bangunan SMK Negeri 1 Lubuk Pakam Tahun Ajaran 2014/2015. Hasil uji coba angket Minat Memilih Kompetensi Keahlian diperoleh 25 butir soal dari 25 butir yang diuji cobakan, koefisien reliabilitas $=0,846$ dan termasuk kategori sangat tinggi.

Hasil penelitian, angket Minat Memilih Kompetensi Keahlian dengan koefisien reliabilitas = 0,661 dan termasuk kategori tinggi. Berdasarkan pengujian hipotesis dapat disimpulkan: 1) Terdapat hubungan linear yang positif dan berarti antara Minat Memilih Kompetensi Keahlian dengan Hasil Belajar Menggambar Dengan Autocad dengan besar korelasi $r_{x y}=0.375>r_{\text {tabel }}=0,361$ dan thitung $=$ 2,140> tabel $=1,701$. 2) Minat Memilih Kompetensi Keahlian dikategorikan cenderung cukup. 3) Terdapat hubungan linear yang positif dan berarti antara Minat Memilih Kompetensi Keahlian dengan Hasil Belajar Menggambar Dengan Autocad pada siswa kelas XI Teknik Gambar Bangunan SMK Negeri 1 Lubuk Pakam Tahun Ajaran 2014/2015. Hal ini dibuktikan dengan hasil perhitungan korelasi antar variabel yang memberikan nilai $r_{x y}=0,375$ oleh karena $r_{x y}=(0.375>0,361)$, maka dapat disimpulkan terdapat hubungan yang signifikan antara Minat Memilih Kompetensi Keahlian dengan Hasil Belajar Menggambar Dengan Autocad. 4) Hasil Belajar Menggambar Dengan Autocad pada siswa kelas XI Teknik Gambar Bangunan SMK Negeri 1 Lubuk Pakam Tahun Ajaran 2014/2015 dikategorikan cenderung cukup. Dengan demikian Minat Memilih Kompetensi Keahlian mempunyai linear yang positif dan berarti dengan Hasil Belajar Menggambar Dengan Autocad.
\end{abstract}

Kata Kunci :Kompetensi Keahlian, Hasil Belajar, Autocad

\begin{abstract}
This study aimed to know: There is a positive and significant relationship between interest Choosing Against Competency Learning Outcomes Drawing With Students In Class XI Autocad Architecture Engineering SMK 1 Lubukpakam the Academic Year 2014/2015. The trial results questionnaire Interests Choosing Skills Competency earned 25 items of the 25 items tested, the reliability coefficient $=0.846$ and categorized as very high.

Results of the study, a questionnaire Interests Competency Choosing the reliability coefficient $=0.661$ and included high category. Based on hypothesis testing can be concluded: 1) There is a linear relationship between the positive and meaningful Interests Choosing the Skill Competency Learning Outcomes Drawing with Autocad with a correlation $r x y=0.375>$ rtabel $=0.361$ and $t=2,140>t$ table $=1.701 .2)$ Interest Select XI Skill Competency categorized tend to be pretty. 3) There is a linear relationship between the positive and meaningful Interests Choosing the Skill Competency Learning Outcomes Drawing with Autocad in class XI student of Architecture Engineering SMK 1 Lubukpakam the Academic Year 2014/2015. This is evidenced by the results of the calculation of correlations between variables which give the value of $r x y=0.375$ therefore $r x y$ $=(0.375>0.361)$, it can be concluded there is a significant relationship between interest Choosing Skills
\end{abstract}


Competency in Learning Outcomes Drawing with Autocad. 4) Learning Outcomes Drawing with Autocad in class XI student of Architecture Engineering SMK 1 Lubukpakam Academic Year 2014/2015 categorized tend to be pretty. Thus Interests Choosing Skills Competency has a positive and significant linear with Learning Outcomes Drawing with Autocad.

Keywords: Competence Expertise, Learning Outcomes, Autocad

\section{Pendahuluan}

Pendidikan menengah kejuruan adalah salah satu satuan pendidikan yang bertujuan untuk mempersiapkan lulusannya menjadi tenaga kerja yang mempunyai pengetahuan dan keterampilan tingkat menengah sesuai dengan bidangnya.

SMK adalah satuan pendidikan formal pada jenjang sekolah menengah di Indonesia sebagai lanjutan dari Sekolah Mengengah Pertama (SMP) atau Madrasah Tsanawiyah (MTs). SMK sebagai bagian integral dari sistem pendidikan di Indonesia memegang peranan penting dalam meningkatkan SDM khususnya dalam mempersiapkan tenaga kerja menengah.

Di SMK Negeri 1 Lubuk Pakam merupakan satuan pendidikan formal yang memiliki : tiga (3) bidang studi keahlian yakni : Teknologi dan Rekayasa, Teknologi Informasi dan Komunikasi, serta Seni, Kerajinan dan Pariwisata. Memiliki tujuh (7) Program studi Kehalian yakni : Teknik Bangunan, Teknik Ketenagalistrikan, Teknik Mesin, Teknik Otomotif, Teknik Elektronika, Teknik Komputer dan Informatika, Tata Kecantikan. Para lulusannya diharapkan mampu bersaing di dunia usaha dan industri khususnya pada program studi keahlian Teknik Bangunan yang memiliki dua (2) Kompetensi Keahlian yaitu Teknik Gambar Bangunan dan Teknik Konstruksi Kayu.

Kompetensi keahlian Teknik Gambar Bangunan adalah spesialisasi dalam suatu program studi keahlian yang membekali peserta didik dengan pengetahuan, keterampilan dan kemampuan untuk melakukan pekerjaan sebagai drafter / juru gambar dalam pekerjaan perecanaan / pelaksanaan bangunan. Hal ini sesuai dengan Peraturan Presiden Indonesia Nomor 8 Tahun 2012 Tentang Kerangka Kualifikasi Nasional Indonesia (KKNI) bahwa : " Capaian pembelajaran adalah kemampuan yang diperoleh melalui internalisasi pengetahuan, sikap, keterampilan, kompetensi dan akumulasi pengalaman kerja".
Untuk mewujudkan harapan tersebut, SMK Negeri 1 Lubuk Pakam memiliki banyak mata pelajaran pendukung agar tercapainya lulusan yang bermutu. Salah satunya adalah Menggambar dengan Autocad. Mata pelajaran Menggambar dengan Autocad merupakan salah satu mata pelajaran yang dipelajari di kelas XI dan XII yang memiliki konsep dasar dimana siswa dituntun untuk mempunyai pengetahuan, keterampilan dan kemampuan menggunakan software Autocad untuk membuat sebuah rancangan gambar yang dapat menjadi bekal bagi peserta didik nantinya untuk dapat diterapkan dan dikembangkan dalam dunia kerja atau berwirausaha di studio gambar.

Dengan melihat nilai rata-rata siswa yang mengalami penurunan setiap tahunnya, maka peneliti ingin mengetahui hubungan minat sewaktu memasuki kompetensi keahlian Teknik Gambar Bangunan terhadap hasil belajar Menggambar dengan Autocad siswa di SMK Negeri 1 Lubuk Pakam.

Rendahnya minat dalam memilih kompetensi keahlian Teknik Gambar Bangunan dapat dilihat dari Pendaftar Siswa Baru (PSB) SMK Negeri 1 Lubuk Pakam pada tahun ajaran 2013 / 2014 Kompetensi Keahlian Teknik Gambar Bangunan sebanyak 72 orang sedangkan yang diterima sebanyak 64 orang.

Untuk itu, pemilihan kompetensi keahlian yang sesuai dengan minat siswa adalah hal yang harus diperhatikan oleh pihak-pihak terkait seperti sekolah dan orang tua. Siswa yang berminat memilih kompetensi keahlian diarahkan sedemikian rupa agar dapat terjun langsung ke dunia kerja sesuai dengan keinginannya.

Idealnya siswa menguasai semua mata pelajaran yang terdapat pada program normatif, adaktif dan produktif. Namun, penguasaan Menggambar dengan Autocad yang terdapat dalam program produktif perlu mendapat perhatian, karena mata pelajaran ini mempunyai hubungan erat dengan penggunaan komputer. Mata pelajaran ini 


\section{Hubungan Minat Memilih Kompetensi Keahlian Terhadap Hasil Belajar Menggambar dengan Autocad pada Siswa Kelas XI Teknik Gambar Bangunan SMK Negeri 1 Lubuk Pakam}

sanggat berguna karena merupakan syarat kejuruan yaitu mempunyai hubungan erat dengan mata pelajaran lainnya yang berhubungan dengan program produktif.

Oleh karena itu, mata pelajaran Autocad berhubungan langsung dengan Ilmu Pengetahuan dan Teknologi (IPTEK) terkhusus pada kompetensi keahlian Teknik Gambar Bangunan dan kehidupan sehari-hari yang mempunyai peranan penting dalam meningkatkan sumber daya manusia yang berkualitas. Karena itu, Autocad perlu diajarkan dan dikuasai seluruh peserta didik di SMK dan perguruan tinggi. Maka tidak mengherankan kalau Autocad menjadi perhatian dan sorotan dari berbagai pihak.

Memperhatikan bahwa pentingnya mengetahui minat memilih kompetensi keahlian terhadap mata pelajaran produktif khususnya menggambar dengan autocad, peneliti tertarik melakukan penelitian untuk mengetahui seberapa besar hubungan minat memilih kompetensi keahlian terhadap hasil belajar menggambar dengan autocad pada siswa kelas XI Teknik Gambar Bangunan SMK Negeri 1 Lubuk Pakam tahun ajaran 2014 / 2015.

\section{Kajian Pustaka}

\subsection{Hakikat Hasil Belajar Menggambar} dengan Autocad

Belajar adalah perubahan tingkah laku yang relatif mantap berkat latihan dan pengalaman. Belajar sesungguhnya adalah ciri khas manusia dan merupakan bagian dari hidupnya, berlangsung seumur hidup, kapan saja, dan dimana saja, baik di sekolah, di kelas, di jalanan dalam waktu yang tidak dapat ditentukan sebelumnya. Satu hal yang sudah pasti bahwa belajar yang dilakukan manusia senantiasa dilandasi itikad dan maksud tertentu.

Slameto (2003:2) mengatakan bahwa belajar adalah suatu proses usaha yang dilakukan seseorang untuk memperoleh suatu perubahan tingkah laku yang baru secara keseluruhan sebagai hasil pengalamannya sendiri dalam interaksi dengan lingkungannya yaitu interaksi belajar mengajar.

Menurut Natawidjaja (1992:22) belajar adalah suatu pembentukan, perubahan, penambahan dan pengurangan perilaku individu.
Menurut Gagne dalam Dimyati (2009:10), belajar adalah seperangkat alat kognitif yang mengubah sifat stimulasi lingkungan Dari uraian di atas dapat disimpulkan bahwa belajar adalah suatu proses yang dilakukan dan dialami seseorang untuk mendapatkan perubahan dalam bentuk tingkah laku secar menyeluruh sebagai hasil pengalaman belajar yang diperoleh dalam hubungan lingkungan belajarnya.

Menurut Nana Sudjana (2008:12) hasil belajar adalah suatu akibat dari hasil pembelajaran dengan menggunakan alat pengukuran, yaitu berupa tes yang disusun secara terencana, baik tes tertulis, tes lisan maupun tes perbuatan Hasil belajar dinyatakan dalam bentuk tujuan-tujuan dan perilaku atau unjuk kerja. Hasil belajar dinyatakan diperoleh dengan mengacu pada terjadinya perubahan tingkah laku pada diri siswa yang dapat diamati dan diukur dalam bentuk perubahan pengetahuan, sikap dan keterampilan. Perubahan tersebut dapat diartikan terjadinya peningkatan dan pengembangan yang lebih baik dibandingkan dengan sebelumnya. Hasil belajar yang dimaksud dalam penelitian ini adalah hasil belajar Menggambar Dengan Autocad yaitu pencapaian peningkatan kemampuan psikomotor dan keterampilan siswa yang diukur dengan menggunakan tes perbuatan pada saat melakukan praktek.

Autocad adalah perangkat lunak komputer untuk menggambar 2 dimensi dan 3 dimensi yang dikembangkan oleh Autodesk. Produk Autocad secara keseluruhan adalah software yang paling banyak digunakan di dunia. Autocad merupakan sebuah program yang biasa digunakan untuk tujuan tertentu dalam menggambar serta merancang dengan bantuan komputer dalam pembentukan model serta ukuran 2 dan 3 dimensi atau lebih dikenali sebagai "Computer Aided Drafting and Design Program (CAD)". Program ini dapat digunakan dalam sebuah bidang kerja terutama sekali dalam bidang-bidang yang memerlukan keterampilan khusus seperti bidang mekanikal engineering, teknik sipil, arsitektur, grafik desain dan semua bidang yang berkaitan dengan menggunakan CAD.

Berdasarkan uraian di atas tentang hakikat hasil belajar menggambar dengan Autocad adalah suatu akibat dari proses pembelajaran 


\section{Asmita Silitonga - Toyama Sitompul}

menggambar dengan menggunakan Autocad dalam mencapai tujuan pengajaran yang diwujudkan dengan nilai.

\subsection{Hakikat Minat Memilih Komptensi Keahlian \\ 2.2.1 Hakikat Minat}

Slameto (2009:89) menyatakan bahwa minat adalah suatu rasa lebih suka atau rasa keterikatan pada suatu hal atau aktivitas. Menurut Hurlock (2001:114), minat merupakan sumber motivasi yang mendorong orang untuk melakukan apa yang mereka inginkan bila bebas memilih. Suatu rasa lebih suka dan rasa keterikatan pada suatu hal atau aktivitas, tanpa ada yang menyuruh Pintrich dan Schunk dalam anonim defenisi minat menjadi tiga yaitu:

a. Minat pribadi, yaitu minat yang berasal dari pribadi atau karakteristik individu yang relatif stabil. Biasanya minat pribadi diasumsikan langsung ke beberapa aktivitas atau topik

b. Minat situasi, yaitu minat yang berhubungan dengan kondisi lingkungannya seperti ruangan kelas, komputer dan buku teks yang dapat membangkitkan minat

c. Minat dalam rumusan psikologi,yaitu perpaduan antara minat pribadi dengan minat situasi

Pintrich dan Schunk dalam cosynook menyebutkan aspek - aspek minat adalah sebagai berikut:

a. Sikap umum terhadap aktivitas (general attitude toward the activity) sikap umum disini maksudnya adalah sikap yang dimiliki oleh individu, yaitu perasaan suka atau tidak suka terhadap aktivitas

b. Pilihan spesifik untuk menyukai aktivitas (spesific preference for or liking the activity). Individu akan memutuskan pilihannya untuk menyukai aktivitas tersebut

c. Merasa senang dengan aktivitas (enjoyment of the activity), yaitu perasaan senang individu terhadap segala sesuatu yang berhubungan dengan aktivitasnya

d. Aktivitas tersebut mempunyai arti atau penting bagi individu (personel importance or significance of the activity to the individual) individu merasa bahwa aktivitas yang dilakukannya sangat berarti

e. Adanya minat intrisik dalam isi aktivitas (instrinsic interest in the content of activity). Dalam aktivitas tersebut terdapat perasaan yang menyenangkan.

f. Berpartisipasi dalam aktivitas (reported choise of or participation in the activity). Individu akan berpartisipasi dalam aktivitas itu karena menyukainya

Hurlock (2001:116), minat mempunyai 2 aspek, yaitu aspek kognitif dan aspek afektif. Aspek kognitif didasarkan atas konsep yang dikembangkan siswa mengenai bidang yang berkaitan dengan minat. Misalnya dari aspek kognitif dari minat siswa terhadap sekolah. Apabila siswa menganggap sekolah sebagai tempat belajar tentang hal-hal yang telah menimbulkan rasa ingin tahu dan mendapatkan kesempatan untuk bergaul dengan teman sebaya yang tidak didapai pada masa prasekolah. Minat siswa terhadap sekolah akan sangat berbeda bila minat itu didasarkan atas konsep sekolah yang menekankan frustasi dan pengekangan oleh peraturan dan kerja keras untuk menghafalkan pelajaran.

Dari uraian di atas, maka dapat diketahui bahwa minat merupakan ketertarikan atau kecenderungan hati seseorang yang memiliki perhatian terhadap suatu objek disertai keingintahuan yang didorong oleh perasaan senang untuk mempelajari maupun membuktikannya lebih lanjut serta memilih untuk berhubungan lebih aktif terhadap objek tertentu.

\subsubsection{Hakikat Kompetensi Keahlian}

Pendidikan menegah kejuruan adalah pendidikan pada jenjang pendidikan menegah yang mengutamakan pengembangan kemampuan siswa untuk melaksanakan jenis pekerjaan tertentu. Selanjutnya disebut pulak bahwa tujuan pendidikan menengah kejuruan adalah mengutamakan penyiapan siswa untuk memasuki lapangan kerja serta mengembangkan sikap professional. Dari 


\section{Hubungan Minat Memilih Kompetensi Keahlian Terhadap Hasil Belajar Menggambar dengan Autocad pada Siswa Kelas XI Teknik Gambar Bangunan SMK Negeri 1 Lubuk Pakam}

uraian di atas dapat menunjukan bahwa sasaran menghantarkan lulusan untuk mampu mengaplikasikan ilmu dan keterampilan yang diperoleh pada lapangan pekerjaan.

Program studi keahlian adalah jurusan dalam suatu bidang studi keahlian. Sedangkan, kompetensi keahlian adalah spesialisasi dalam suatu program studi keahlian. Untuk mempersiapkan siswa memasuki lapangan kerja serta mengembangkan sikap professional dalam bidang tertentu, maka pemilihan kompetensi keahlian yang tepat merupakan kuncinya. Dari uraian di atas, maka siswa yang mempunyai minat memilih kompetensi keahlian akan menunjukan sikap seperti perhatian terhadap hal-hal yang berkaitan dengan sekolah tersebut, menunjukan keinginan dan kesungguhan, menunjukan dorongan untuk berusaha masuk sekolah tersebut serta menunjukan rasa senang bila masuk SMK.

Berdasarkan uraian tentang hakikat minat memilih kompetensi keahlian di atas maka dapatlah disimpulkan bahwa yang dimaksud dengan minat memilih kompetensi keahlian dalam penelitian ini adalah keinginan memilih kompetensi keahlian atas dasar adanya pengetahuan dan pemahaman tentang tujuan pendidikan SMK serta adanya anggapan bahwa hal tersbut berguna bagi dirinya hingga seseorang tersebut tertarik, senang dan ingin mengikuti proses belajar mengajar di SMK tersebut.

\subsection{Hipotesis Penelitian}

Berdasarkan kerangka berfikir yang telah dikemukakan, dapat diajukan hipotesis penelitian sebagai berikut:

Terdapat hubungan positif dan signifikan antara minat memilih kompetensi keahlian terhadap hasil belajar menggambar dengan Autocad pada siswa kelas XI teknik gambar bangunan SMK

\section{Metodologi Penelitian}

Penelitian ini dilakukan pada siswa kelas XI KompetensiKeahlian Teknik Gambar Bangunan SMK Negeri 1 Lubuk Pakam tahun ajaran 2014 / 2015.Penelitian dilaksanakan mulai bulan Mei 2014 sampai Maret 2015.

Populasi dalam penelitian ini adalah seluruh siswa kelas XI Kompetensi Keahlian Teknik Gambar Bangunan SMK Negeri 1 Lubuk Pakam tahun ajaran 2014 / 2015 yang terdiri dari 1 kelas dengan jumlah 30 orang.

Sesuai dengan pendapat Arikunto (2003:107) menjelaskan apabila subjeknya kurang dari 100 orang, lebih baik diambil semua sehingga penelitiannya merupakan penelitian populasi. Mengingat jumlah siswa kelas XI kompetensi keahlian teknik gambar bangunan SMK Negeri 1 Lubuk Pakam tahun ajaran 2014 / 2015 yang terdiri dari 1 kelas sebanyak 30 orang, maka seluruh siswa dijadikan sampel penelitian sehingga penelitian ini merupakan penelitian populasi.

\subsection{Teknik Pengumpulan Data}

Pengumpulan data sangat berhubungan erat dengan masalah dan tujuan dalam proses pengajuan hipotesis. Untuk itu dalam pengumpulan data harus dilakukan dengan cermat untuk menghindari kesalahan yang mungkin terjadi.Dalam penelitian ini ada dua variabel yaitu :

a. Minat memilih kompetensi keahlian dijaring dengan menggunakan angket tertutup.

b. Hasil belajar menggambar dengan Autocad menggunakan tes perbuatan berupa observasi langsung pada saat praktek.

\subsection{Hasil Uji Coba Instrumen}

Instrumen yang baik harus memenuhi dua persyaratan yaitu valid dan reliabel. Untuk itu, uji coba instrumen penelitian dilakukan pada siswa kelas XII sebanyak 28 orang siswa Kompetensi Keahlian Teknik Gambar Bangunan SMK Negeri 1 Lubuk Pakam.

Alasan dilakukannya uji coba instrumen pada siswa kelas XII adalah karena mereka telah mempelajari mata pelajaran Menggambar Dengan Autocad di kelas XI.

\subsubsection{Minat Memilih Kompetensi Keahlian (x)}

a. Uji Validitas

Instrumen minat memilih kompetensi keahlian berbentuk angket, maka validitas angket dihitung dengan menggunakan 


\section{Asmita Silitonga - Toyama Sitompul}

rumus Korelasi Product Moment dalam Arikunto (2009:171) yaitu:

$r_{x y}=\frac{(N \cdot \Sigma X Y)-(\Sigma X)(\Sigma Y)}{\sqrt{\left\{N \Sigma X^{2}-(\Sigma X)^{2}\right\}\left\{N \Sigma Y^{2}-(\Sigma Y)^{2}\right\}}}$

b. Uji Reliabilitas

Reliabilitas angket adalah ketetapan hasil angket yang mantap dan mempunyai taraf kepercayaan yang tinggi dan apabila hasilnya berubah-ubah, perubahan yang terjadi dapat dikatakan berarti. Untuk menguji reliabilitas angket, ditentukan dengan menggunakan rumus Alpha oleh Arikunto (2009:180), yaitu:

$$
r_{11}=\left(\frac{k}{k-1}\right)\left(1-\frac{\sum \sigma_{b}{ }^{2}}{\sigma_{t}{ }^{2}}\right)
$$

\subsubsection{Hasil Belajar Menggambar dengan Autocad (Y) \\ Menggunakan data DKN SMK \\ Negeri 1 Lubuk Pakam Tahun \\ Ajaran 2013/2014}

\subsection{Teknik Analisis Data}

Teknik analisis data dilakukan secara deskriptif jenis studi korelasi

Data Yang dianalisis dalam penelitian ini adalah:

\subsubsection{Diskripsi Data Penelitian}

Mendeskripsikan data variabel penelitian, di analisa dengan menggunakan harga rata-rata $(\mathrm{M})$ dan standar deviasi (SD) dari masing-masing variabel penelitian. Untuk menghitung $\mathrm{M}$ olehArikunto (2009:284) dan SDoleh digunakan rumus :

$$
\mathrm{M}=\frac{\sum \mathrm{X}}{\mathrm{N}}
$$

\subsubsection{Uji Kecendrungan}

Uji kecenderungan di analisa dengan menggunakan harga rata-rata ideal (Mi), standar deviasi ideal (SDi). Adapun rumus untuk rata-rata ideal (Mi) dan standar deviasi ideal (SDi) adalah :

$$
\mathrm{Mi}=\frac{\text { SkorTertinggi }+ \text { SkorTerendah }}{2}
$$

\subsubsection{Uji Persyaratan Analisis}

Uji persyaratan analisis yang dilakukan untuk mengetahui apakah data variabel $X$ linier terhadap variabel $Y$, untuk itu dilakukan uji normalitas dan uji linearitas.

Uji normalitas terhadap data varibel penelitian yang dilakukan dengan menggunakan rumus chi-kuadrat oleh Arikunto (2009:312) seperti sebagai berikut:

$$
\mathrm{X}^{2}=\sum\left[\frac{(\mathrm{fo}-\mathrm{fh})^{2}}{\mathrm{fh}}\right]
$$

Uji Linearitas, data variabel bebas $(\mathrm{X})$ linier terhadap data variabel terikat $(\mathrm{Y})$, maka dilakukan dengan uji linier sederhana $Y$ atas $X$ seperti yang dikemukakan Arikunto (2009:372) dengan persamaan sebagai berikut:

$$
Y=a+b x
$$

Dimana nilai a dan b oleh Sudjana (2003:8) sebagai berikut:

$$
\begin{aligned}
& a=\frac{(\Sigma Y)(\Sigma X)^{2}-(\Sigma X)(\Sigma X Y)}{N \Sigma X^{2}-(\Sigma X)^{2}} \\
& \mathrm{~b}=\frac{\mathrm{N} \Sigma \mathrm{XY}-(\Sigma \mathrm{X})(\Sigma Y)}{{\mathrm{N} \Sigma \mathrm{X}^{2}-(\Sigma \mathrm{X})^{2}}^{2}}
\end{aligned}
$$

\subsubsection{Pengujian Hipotesis}

Pengujian hipotesis untuk mengetahui adanya hubungan linier yang positif dan signifikan antara minat memilih kompetensi keahlianterhadap hasil belajar menggambar dengan Autocad, digunakan rumus korelasi oleh Arikunto (2009:375) sebagai berikut:

$$
r x y=\frac{(\mathrm{N} \Sigma X Y)-(\Sigma X)(\Sigma Y)}{\sqrt{\left(\Sigma X^{2}\right)-(\Sigma X)^{2}\left(N \Sigma Y^{2}-(\Sigma Y)^{2}\right)}}
$$

Kemudian untuk mengetahui keberartian hubungan antara variabel bebas dan variabel terikat yang diperoleh, dilakukan dengan uji-t seperti yang dikemukakan oleh Sudjana (2003:62) sebagai berikut:

$$
t=\frac{r \sqrt{(n-2)}}{\sqrt{1-r^{2}}}
$$

Besar $t_{\text {hitung }}$ yang diperoleh dikonsultasikan terhadap $t_{\text {tabelpada }}$ taraf signifikan $5 \%$ dengan $\mathrm{dk}=\mathrm{N}-2$. Bila $t_{\text {hitung }}>t_{\text {tabel, }}$ maka disimpulkan bahwa 


\section{Hubungan Minat Memilih Kompetensi Keahlian Terhadap Hasil Belajar Menggambar dengan Autocad pada Siswa Kelas XI Teknik Gambar Bangunan SMK Negeri 1 Lubuk Pakam}

antara variabel bebas dan variabel terikat teerdapat hubungan keberartian.

\section{Hasil Penelitian dan Pembahasan}

\subsection{Minat Memilih Kompetensi Keahlian}

Berdasarkan data variabel Minat Memilih Kompetensi Keahlian (X) yang diperoleh dengan jumlah responden 30 orang siswa, skor tertinggi 86; skor terendah 50; dengan mean (M) $=64,233 ;$ dan standart deviation $(\mathrm{SD})=8,754$. Distribusi frekuensi data variabel Minat Memilih Kompetensi Keahlian (X) dapat dilihat pada Tabel 1.

Tabel 1. Distribusi Frekuensi Minat Memilih Kompetensi Keahlian (X)

\begin{tabular}{cccc}
\hline No & Interval Kelas & $\begin{array}{c}\text { F. } \\
\text { Absolut }\end{array}$ & $\begin{array}{c}\text { F. } \\
\text { Relatif }\end{array}$ \\
\hline 1 & 37,971 s/d 46,725 & 0 & $0 \%$ \\
2 & 46,726 s/d 55,479 & 3 & $10 \%$ \\
3 & 55,480 s/d 64,233 & 14 & $46,667 \%$ \\
4 & 64,234 s/d 72,987 & 9 & $30 \%$ \\
5 & 72,988 s/d 81,741 & 3 & $10 \%$ \\
6 & 81,742 s/d 90,495 & 1 & $3,333 \%$ \\
\hline \multicolumn{2}{r}{ Jumlah } & $\mathbf{3 0}$ & $\mathbf{1 0 0}$ \\
\hline
\end{tabular}

4.2 Hasil Belajar Menggambar dengan Autocad

Berdasarkan data variabel Hasil Belajar Menggambar Dengan Autocad (Y) yang diperoleh dengan jumlah responden 30 orang siswa, nilai tertinggi 87,50; nilai terendah 73; dengan mean $(M)=79,483$; dan standart deviation $(\mathrm{SD})=4,830$. Distribusi frekuensi data Hasil Belajar Menggambar Dengan Autocad (Y) dapat dilihat pada Tabel 2.

Tabel 2. Distribusi Frekuensi Hasil Belajar Menggambar Dengan Autocad (Y)

\begin{tabular}{cccc}
\hline No & Interval Kelas & $\begin{array}{c}\text { F. } \\
\text { Absolut }\end{array}$ & $\begin{array}{c}\text { F. } \\
\text { Relatif }\end{array}$ \\
\hline 1 & 64,993 s/d 69,823 & 0 & $0 \%$ \\
2 & 69,824 s/d 74,653 & 7 & $22,333 \%$ \\
3 & 74,654 s/d 79,483 & 10 & $32,333 \%$ \\
4 & 79,483 s/d 84,313 & 6 & $20 \%$ \\
5 & 84,314 s/d 89,143 & 8 & $25,666 \%$ \\
6 & 89,144 s/d 93,973 & 0 & $0 \%$ \\
\hline & Jumlah & $\mathbf{3 0}$ & $\mathbf{1 0 0}$ \\
\hline
\end{tabular}

4.3 Uji Tingkat Kecendrungan Minat Memilih Kompetensi Keahlian
Untuk mengidentifikasi tingkat kecenderungan Minat Memilih Kompetensi Keahlian (X) digunakan nilai rata-rata deal (Mi) $=62,5$ dan Standart Deviasi (Sdi) $=12,5$. Tingkat kecenderungan Minat Memilih Kompetensi Keahlian dapat dilihat pada Tabel 3.

Tabel 3. Tingkat Kecenderungan Minat Memilih Kompetensi Keahlian (X)

\begin{tabular}{cccc}
\hline Interval Kelas & $\begin{array}{c}\text { F. } \\
\text { Absolut }\end{array}$ & $\begin{array}{c}\text { F. } \\
\text { Relatif }\end{array}$ & Katagori \\
\hline 81,25 s/d keatas & 1 & $3.333 \%$ & Tinggi \\
62,5 s/d 81,25 & 15 & $50 \%$ & Cukup \\
43,75 s/d 62,5 & 14 & $46.667 \%$ & Kurang \\
43,75 s/d kebawah & 0 & $0 \%$ & Rendah \\
\hline Jumlah & 30 & $100 \%$ & \\
\hline
\end{tabular}

Dari tabel 3 di atas diperoleh tingkat kecenderungan Minat Memilih Komptensi Keahlian (X) dapat dideskripsikan menjadi kategori tinggi 1 orang (3.333\%), kategori cukup 15 orang (50\%), dan kategori kurang 14 orang (46.667 \%). Dengan demikian dapat dinyatakan bahwa Minat Memilih Kompetensi Keahlian (X) dari siswa kelas XI Teknik Gambar Bangunan SMK Negeri 1 Lubuk Pakam cenderung cukup.

\subsection{Uji Tingkat Kecendrungan Hasil Belajar Menggambar dengan Autocad \\ Untuk mengidentifikasi tingkat} kecenderungan Hasil Belajar Menggambar Dengan Autocad $(\mathrm{Y})$ digunakan nilai rata-rata deal $(\mathrm{Mi})=70$ dan Standart Deviasi $($ Sdi) $=10$. Tingkat kecenderungan Minat Memilih Kompetensi Keahlian dapat dilihat pada Tabel 4

Tabel 4. Kecenderungan Hasil Belajar Menggambar dengan Autocad (Y)

\begin{tabular}{cccc}
\hline Interval Kelas & $\begin{array}{c}\text { F. } \\
\text { Absolut }\end{array}$ & $\begin{array}{c}\text { F. } \\
\text { Relatif }\end{array}$ & Katagori \\
\hline 85 s/d keatas & 8 & $26,667 \%$ & Tinggi \\
70 s/d 85 & 22 & $73,333 \%$ & Cukup \\
55 s/d 70 & 0 & $0 \%$ & Kurang \\
55 s/d kebawah & 0 & $0 \%$ & Rendah \\
\hline Jumlah & 30 & $100 \%$ & \\
\hline
\end{tabular}

Dari tabel di atas diperoleh tingkat kecenderungan Hasil Belajar Menggambar Dengan Autocad (Y) dapat dideskripsikan menjadi kategori tinggi 8 orang $(26,667 \%)$, kategori cukup 22 orang $(73,333 \%)$. Dengan 


\section{Asmita Silitonga - Toyama Sitompul}

demikian dapat dinyatakan bahwa Hasil Belajar Menggambar Dengan Autocad (Y) dari siswa kelas XI Teknik Gambar Bangunan SMK Negeri 1 Lubuk Pakam cenderung cukup.

\subsection{Uji Persyaratan Analis}

Dalam pengujian analisis statika untuk menguji hipotesis, maka terlebih dahulu dilakukan Uji Normalitas dan Uji Linearitas untuk melihat terpenuhi atau tidak distribusi data yang normal pada tiap variabel penelitian dan linear atau tidak linear tiap hubungan variabel bebas dan variabel terikatnya.

\subsubsection{Uji Normalitas}

Uji normalitas adalah salah satu uji persyaratan analitis yang bertujuan untuk mengetahui apakah data variabel penelitian berdistribusi normal atau tidak.. Pengujian ini dilakukan dengan menggunakan rumus Chi kuadrat $\left(X^{2}\right)$ dengan ketentuan jika $X^{2}$ hitung $<X^{2}$ tabel pada taraf signifikasi $5 \%$ dengan $\mathrm{dk}=\mathrm{K}-1$. Dalam hal ini jumlah kelas yang didasarkan pada interval kelas kurva normal, sehingga $\mathrm{dk}=5$. Berikut ini sajian dalam bentuk tabel 5 hasil analisis normalitas data penelitian.

Tabel 5. Ringkasan Hasil Analisis Normalitas Variabel Penelitian

\begin{tabular}{lccc}
\hline Variabel Penelitiaan & dk & Xhitung & $\chi_{\text {tabel }}$ \\
\hline Minat Memilih & & & \\
Kompetensi Keahlian & 5 & 4,731 & \\
$(X)$ & & & 11,070 \\
$\begin{array}{l}\text { Menggambar } \\
\text { Dengan Autocad (Y) }\end{array}$ & 5 & 8,238 & \\
\hline
\end{tabular}

Dari tabel 5 di atas dapat dilihat uji normalitas data masing-masing variabel penelitian diperoleh bahwa $\chi_{\text {hitung }}<\chi_{\text {tabel }}$ pada taraf signifikansi 5\%, sehingga dapat disimpulkan bahwa kedua variabel penelitian adalah berdistribusi normal

\subsubsection{Uji Linearitas dan Keberartian}

Uji linearitas digunakan untuk mengetahui apakah hubungan variabel bebas $X$ dengan variabel terikat $Y$ linear atau tidak. Yaitu Minat memilih Komptensi Keahlian $(X)$ dan Hasil Belajar Menggambar Dengan Auticad (Y).

Berikut ini pada tabel 6 disajikan ringkasan analisis varians yang menguji kelinearan dan keberartian persamaan regresi Hasil Belajar Menggambar Dengan Autocad dengan Minat Memilih Kompetensi Keahlian. Perhitungan selengkapnya dapat dilihat pada lampiran 12. Diperoleh persamaan regresi $Y$ atas $X$ yaitu $Y=79,647+0,119 X$

Tabel 6. Ringkasan ANAVA untuk Persamaan Regresi Y atas X

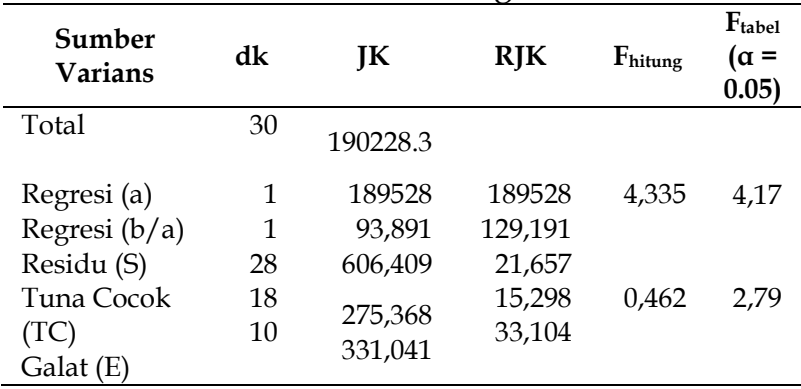

Dari Tabel 6 di atas dapat dilihat bahwa $F_{\text {hitung }}=0,462<2,79$ sehingga persamaan

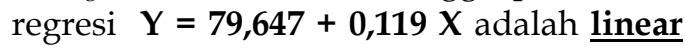
pada taraf signifikan $5 \%$.

Selanjutnya, untuk uji keberartian persamaa regresi ternyata $F_{\text {hitung }}=4,335>$ $\mathrm{F}_{\text {tabel }}=4,17$ didapat persamaan regresi tersebut adalah berarti. Sehingga dapat disimpulkan bahwa koefisien arah persamaan regresi $\mathrm{Y}$ atas $\mathrm{X}$ mempunyai hubungan yang linear dan berarti pada taraf signifikan 5\%.

\subsection{Uji Hipotesis Penelitian}

Dari perhitungan Korelasi Product Moment diperoleh koefisien korelasi antara $X$ dengan $Y$ $=0,375$; sedangkan $r_{\text {tabel }}$ dengan $\mathrm{N}=30$ dan taraf signifikansi 5\% sebesar 0,361. Dengan demikian harga $r_{x y}>r_{\text {tabel }}(0.375>0,361)$. Selanjutnya dilakukan uji keberartian korelasi dengan menggunakan Uji-t diperoleh $\mathrm{r}_{\text {hitung }}$ 2,140. Harga $r_{\text {tabel }}$ untuk $\mathrm{N}=30$ pada taraf signifikan $5 \%$ adalah 1.701. Oleh karena $t_{\text {hitung }}>t_{\text {tabel }}(2,140$ $>$ 1.701) maka dapat dikatakan bahwa terdapat hubungan antara Minat Memilih Kompetensi Keahlian $(X)$ dengan Hasil Belajar Mengggambar Dengan Autocad (Y).

Berikut ini disajikan ringkasan hasil perhitungan korelasi antar variabel penelitian pada tabel 7 .

Tabel 7. Ringkasan Hasil Perhitungan Korelasi Antar Variabel

Korela Koefisien korelasi Harga t $(\mathrm{dk}=$




\section{Hubungan Minat Memilih Kompetensi Keahlian Terhadap Hasil Belajar Menggambar dengan Autocad pada Siswa Kelas XI Teknik Gambar Bangunan SMK Negeri 1 Lubuk Pakam}

\begin{tabular}{ccccc}
\hline si & \multicolumn{2}{c}{$(\mathrm{N}=30, \mathrm{a}=0,05)$} & \multicolumn{2}{c}{$28, \mathrm{a}=0,05)$} \\
\cline { 2 - 5 } $\mathrm{r}_{\mathrm{xy}}$ & $\mathrm{r}_{\text {hitung }}$ & $\mathrm{r}_{\text {tabel }}$ & $t_{\text {hitung }}$ & $\mathrm{t}_{\text {tabel }}$ \\
\cline { 2 - 5 } & 0.375 & 0,361 & 2,140 & 1.701 \\
\hline
\end{tabular}

Dari tabel 7 di atas dapat digambarkan paradigma hasil penelitian sebagai berikut:

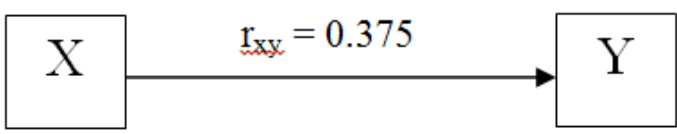

Gambar 1. Paradigma Hasil Penelitian

Dari hasil perhitungan di atas, dapat disimpulkan hipotesis penelitian yang diajukan bahwa terdapat hubungan yang linier dan berarti antara Minat Belajar dengan Hasil Belajar Menggambar Dengan Autocad serta teruji kebenarannya.

\section{Kesimpulan, Implikasi dan Saran}

\subsection{Kesimpulan}

Berdasarkan hasil penelitian yang telah diuraikan pada Bab IV, maka dapat disimpulkan : Terdapat hubungan yang positif dan berarti antara Minat Memilih Kompetensi Keahlian dengan Hasil Belajar Menggambar Dengan Autocad pada siswa kelas XI Teknik Gambar Bangunan SMK Negeri 1 Lubuk Pakam Tahun Ajaran 2014/2015. Hal ini dibuktikan dengan hasil perhitungan korelasi antar variabel yang memberikan nilai $r_{x y}=0,375$ oleh karena $r_{x y}=(0.375>0,361)$, maka dapat disimpulkan terdapat hubungan yang signifikan antara Minat Memilih Kompetensi Keahlian dengan Hasil Belajar Menggambar Dengan Autocad.

\subsection{Implikasi}

Berdasarkan hasil penelitian dan kesimpulan penelitian yang ditemukan dan dengan diterimanya hipotesis, maka upaya meningkatkan Hasil Belajar Menggambar Dengan Autocad adalah dengan meningkatkan mengenai Minat Memilih Kompetensi Keahlian siswa. Upaya yang dapat dilakukan guru adalah dengan memberikan dorongan dalam berinteraksi dengan lingkungannya, menarik perhatian siswa dengan menjelaskan pekerjaan yang dapat dikerjakan setelah lulus, memberi petunjuk dalam melakukan aktivitas dan membuat siswa merasa senang dalam melakukan aktivitas. Dengan adanya upaya ini, minat memilih kompetensi keahlian dapat ditingkatkan.

\subsection{Saran}

Berdasarkan simpulan dan implikasi penelitian di atas, maka penulis menyarankan:

a. Untuk meningkatkan Minat Memilih Kompetensi Keahlian Teknik Gambar Bangunan, diharapkan guru membantu siswa, salah satunya caranya dengan memberi ruang kepada siswa untuk mengekspresikan minatnya.

b. Untuk meningkatkan hasil belajar Menggambar Dengan Autocad, diharapkan siswa dapat mempertahankan keinginan untuk mempelajari mata pelajaran Menggambar Dengan Autocad. serta peran sekolah dan guru untuk menciptakan lingkungan belajar yang mendukung, memotivasi siswa, memberikan penjelasan tentang pentingnya mata pelajaran Menggambar Dengan Autocad terhadap mata pelajaran lainnya.

c. Untuk sekolah dan laboratorium autocad kiranya lebih memperhatikan dan melakukan perawatan komputer yang ada.

d. Perlu diadakan penelitian lebih lanjut tentang hubungan minat memilih kompetensi keahlian terhadap hasil belajar menggambar dengan autocad untuk memperluas hasil penelitian.

\section{Daftar Pustaka}

Anonim. (2014). Defenisi minat. Diakses pada 02 Februari 2015 dari http://www.psikologiku.com/pengerti an-minat-menurut-para-ahli-psikologi/ cosynook. (2013). Teori minat. Diakses pada 02 Februari $2015 \quad$ dari https://cosynook.wordpress.com/2013/02/14 teori-minat/

Dimyati dan Mudjiono. (2009). Belajar Dan Pembelajaran. Jakarta: Rineka Cipta.

Fitriyah, Lailatul dan Jauhar, Mohammad. (2014). Pengantar Psikologi Umum. Jakarta: Prestasi Pustakarya.

Hurlock, Elizabeth B. (2001). Perkembangan Anak. (Terjemahan dr. Med. Meitasari 
Tjadrarasa). Jakarta: Erlangga. Buku asli diterbitkan tahun 1978.

Lisnawaty Panjaitan. (2010). Hubungan Antara Minat Memilih Jurusan Tata Busana Dan Kelengkapan Fasilitas Belajar Di Rumah Dengan Hasil Belajar Program Diklat Menjahit Dengan Mesin Pada Siswa Kelas X SMK Negeri 1 Kisaran T. A 2009 / 2010. Skripsi. Medan: UNIMED.

Muhibbin Syah. (2003). Psikologi Pendidikan : Dengan Pendekatan Baru. Bandung: Remaja Rosdakarya.

Natawidjaja. (1992). Psikologi Pendidikan. Jakarta: Depdikbud.

Pusat Bahasa Departemen Pendidikan Nasional. (2002). Kamus Besar Bahasa Indonesia Edisi Ketiga. Jakarta: Balai Pustaka.

Sefrina, Andin. (2013). Deteksi Minat Bakat Anak. Yogyakarta: Media Pressindo

Slameto. (2003). Belajar dan faktor-faktor yang mempengaruhinya. Jakarta : Rineka Cipta

Sudjana, N. (2002). Metode Statistik. Bandung: Tarsito

Sudjana, Nana. (2008). Penilaian Hasil Proses Belajar Mengajar. Bandung: Remaja Rosdakarya

Suharsimi, Arikunto (2003). Manajemen Penelitian. Jakarta: Rineka Cipta.

Sudjana, N. (2002). Metode Statistik. Bandung: Tarsito

Sudjana, Nana. (2008). Penilaian Hasil Proses Belajar Mengajar. Bandung: Remaja Rosdakarya.

Sudjana. (2003). Teknik Analisis Regresi dan Korelasi Bagi Para Peneliti. Bandung: Tars

Sugiyono. (2010). Statistika untuk Penelitian. Bandung: Alfabeta

Walgito. (2004). Pengantar Psikologi Umum.

Yogyakarta: Andi 